\title{
Change in construction: a critical perspective
}

Scott Fernie $^{1}$, Roine Leiringer ${ }^{1}$ and Tony Thorpe $^{2}$

1) School of Construction Management and Engineering, University of Reading,

2) Department of Civil and Building Engineering, Loughborough University,

\begin{abstract}
Change within the construction sector has been a central concern of governments and a select few private-sector clients for a considerable time. The discourse of change emanating from organizations concerned with reform in the construction sector reflects these ongoing concerns for change in the sector. The underlying assumptions of the content of change and appropriate change mechanisms in the UK are critically examined and challenged. In particular, the limitations of measurement and best practice are explored. The allegiance to approaches based on measurement and best practice is acontextual, unreflective and insufficient in providing wholly reliable explanations for the relationship between practice and performance. Claims for the use of measurement and best practice by the reform movement must therefore be understood to have limitations and their use approached with caution. The emphasis on best practice is also understood to direct attention away from understanding the legitimacy of current practice and change within the UK construction sector. An agenda for change in the UK construction sector will need to engage with and be more reflective of current managerial practice and past change initiatives. Contextual approaches such as structuration theory offer a way in which to underpin a research framework that could support the reform movement in setting such an agenda.
\end{abstract}

Keywords: benchmarking, best practice, change management, demonstration projects, industry performance, innovation, key performance indicators, organizational change, reform movement

\section{Acknowledgement}

This is a pre-print version of the article: Fernie, S., Leiringer, R. and Thorpe, T. (2006). Rethinking change in construction: a critical perspective. Building Research and Information, 34(2), 91-103. [Copyright Taylor \& Francis]

Building Research and Information is available online at: http://www.tandf.co.uk/journals/titles/09613218.asp

The article is available at: http://pdfserve.informaworld.com/741268_731392193_741631499.pdf 


\section{Introduction}

Change within the construction sector has been a central concern of the UK Government and a select few private-sector clients for some considerable time (Murray and Langford, 2003). The discourse of change emanating from organizations concerned with reform in the construction sector reflects these concerns regarding the need for change in the construction sector. A recent article in Construction Manager (2004) set out to assess the success of a decade of UK industry reports and initiatives that have emerged from those concerned with reform. However, these views were largely unreflective of why reform had been largely unforthcoming. Following on from a number of explorations and critics of the reform movement (cf. Green and May, 2003; Barrett and Barrett, 2004), the present paper attempts to contribute to an understanding of why change and reform in the construction sector continue to fall short of the aspirations outlined in what is described here as the discourse of change mobilized by the reformers. In doing so, it is argued that reflection on the content of this discourse will contribute to a wider debate and deeper understanding about the nature and extent of change in the construction sector.

A discourse is typically defined as a:

"connected set of statements, concepts, terms and expressions which constitute a way of talking and writing about a particular issue, thus framing the way people understand and act with respect to that issue” (Watson, 1997, p. 219)

or

"an interrelated set of texts and the practice of their production, dissemination, and reception that brings an object into being.” (Phillips and Hardy, 2002, p. 3)

Drawing on these definitions, it is possible to argue that in the construction sector:

"a network comprising a diverse range of interest groups, quangos, government outreach bodies and membership clubs.“(Green and May, 2005, p. 4)

disseminate a connected set of statements, concepts, terms and expressions regarding change in the construction sector - a discourse. Of course, within the construction sector (and probably within the network of reformers), it is likely that there exist multiple discourses that overlap, supersede, compete, combine and coexist (Palmer and Dunford, 2002). In this sense, various dynamic discourses exist and are mobilized by disparate stakeholders:

"[to] provide frameworks for debating the value of one way of talking about reality over other ways.” (Parker, 1992, p. 4)

The complexity involved in understanding how various discourses are constructed and drawn upon by disparate stakeholders and mobilized for a variety of reasons, e.g. as political, economic or social, is considerable. This complexity, however, does not discount the value of exploring a single discourse and deconstructing its statements, 
concepts, terms and expressions. Indeed, the discourse focused on in this paper is arguably the dominant one regarding change in the construction sector. For the purposes of this paper, assumptions underpinning the content of discourse (particularly the concepts) mobilized by what is termed here as the reform movement are challenged. This, however, does not discount the legitimacy of the discourse for the reformers since its persuasive narrative may have a political objective that resonates with their concerns and interests despite any shortcomings in the nature of the concepts inherent in the discourse. Exploring such political legitimacy, however, lies largely outwith the scope of this paper, although it has been touched upon by Green and May (2005) in their exploration of storylines on 'leanness' in the construction sector.

To start, the present paper attempts to deconstruct the discourse mobilized by the reform movement. Thus, the first part is broadly concerned with exploring the content of change advocated. In doing so, it engages with recent and current views expressed by influential policy-makers and their respective organizations that have been instrumental in highlighting the perceived problems facing the construction sector. Particular attention is given to the concept of the transferability of best practice. The second part critiques the assumptions that underpin the content of change mobilized by the reform movement. It is instrumental in framing the limitations inherent in the way change is viewed by the reform movement as acontextual. The third and final part proposes that arguments for reform need to be more reflective of the legitimacy of current practice in the construction sector, its history, the symbiotic relationship between context and practice, and the tacit nature of managerial practice. Simply put, it is necessary to think about change in the context of the past and present as shaping influences regarding what can sensibly be achieved in the future. Notably, this is not an argument against the need for change but rather for a more secure and robust basis upon which 'reformers' should reflect upon and consider change. Neither is the ambition of this paper to be normative or prescriptive in presenting actions to replace those already in place. The aim is instead to reveal limitations in the logic that underpins the discourse and content of change mobilized by the reform movement. In doing so, the authors draw upon a broad and eclectic body of literature. The need for such a critique is not to dismiss the reform movement and its discourse, but to challenge the existing orthodoxy and present an alternative perspective. New perspectives are, thus, presented in order to highlight alternative interpretations, although it is expected that these, in turn, will have to be revised. Whilst this might be considered a case of replacing a certain set of problems with a new set, it is well in line with critical research and critical theory, and the desire of this paper to contribute to a wider debate on the nature and extent of change in the UK construction sector.

\section{Reform movement: discussion}

The reform movement within the UK construction sector is by no means a new phenomenon. The discourse of change espoused by the reform movement is captured, articulated, and rooted within publications and initiatives from 1994 onwards.

- The Latham Report (1994) 
- a significant rise of client power in the sector via the establishment of a construction task force (CTF) in 1997 by John Prescott and Nick Raynsford (Murray, 2003)

- CTF's widely cited Rethinking Construction report (Department of Environment Transport and the Regions, 1998)

- its relatively recent sequel the Accelerating Change report (Strategic Forum for Construction, 2002)

- the Better Public Buildings report (Finch, 2000)

- The Clients’ Charter Handbook (Confederation of Construction Clients, 2000)

- the Modernising Construction report (National Audit Office, 2001)

- the Improving Public Services through Better Construction report (National Audit Office, 2005)

- establishment of Constructing Excellence

The overall coordination of this reform movement is arguably now located predominantly with Constructing Excellence and brings together separate entities such as Rethinking Construction, Construction Best Practice and the Movement for Innovation. Their aim is clearly articulated in the following statement:

Constructing Excellence aims to achieve a step change in construction productivity by tackling the market failures in the sector and selling the business case for continuous improvement. Through focused programmes in Innovation, Best Practice Knowledge, Productivity and Engagement, Constructing Excellence has developed a strategy to deliver the process, product and cultural changes that are needed to drive major productivity improvements in the sector. (Constructing Excellence, 2004, p. 2)

Notably, this aim largely reflects that of its collected constituents' prior objectives and provides a step towards consolidation and integration of industry bodies that is long overdue. Practitioners in the sector have frequently complained of an initiative overload arising from fragmented client and contractor bodies. Further consolidation of these bodies is, therefore, likely to remain a necessary aspiration within the sector since it has long suffered from a lack of highlevel representation by powerful coordinated agencies. Indeed, the fragmented representation at both a public policy and private-sector operational level prompted Woudhuysen and Abley (2004, p. 121) to comment that:

The obscurantist interdependency of the quango crocodiles works against the awkward truth being told - that the construction industry is not being rethought so much as meditated upon and massaged. Yet as successive governments have 
contracted out policy-making on construction and the environment, the quangos' reach has grown at the same rate as their intellectual rigour has declined.

Whilst such musing is highly critical, it does resonate with similar concerns discussed elsewhere within the construction management literature (e.g. Cox and Ireland, 2002; Green, 2002; Green and May, 2003). Notably, these authors challenge the intellectual rigour of calls for change emanating from the reform movement. Nonetheless, the reform movement is largely responsible for the introduction of management initiatives throughout the construction sector and has been given considerable support from government.

\section{Reiterating familiar concerns}

The ongoing commitment to procure regularly from the sector by particular clients is clearly reflected in the change agenda and reveals a motive that is driven by more than altruism. Indeed, note that the dominant position of clients in the reform movement is not serendipitous. Murray (2003), for example, points out that the CTF deliberately excluded contractors. Despite a more balanced representation within the Movement for Innovation and Construction Best Practice Programme, client dominance still prevails. Significant attention has also recently been paid to the construction sector by the public sector as a client. The desire of the public sector to attain 'value for money', increased competition and improved capacity planning for markets where the government has (or could have) significant purchasing power (Office of Government Commerce, 2003) is a significant contributor to calls for change.

The arguments for reform and change presented by the reform movement are therefore ostensibly driven by clients' ongoing dissatisfaction with the sector's performance. This dissatisfaction is not a secret; indeed, it is all too familiar to a sector that has historically been subjected to numerous reviews. A recent review of these reviews edited by Murray and Langford (2003) provides a useful insight into this history. It largely confirms a widely held belief that reviews in the last 60 years share similar messages regarding the sector's performance and only subtle differences regarding explanations of poor performance and recommendations to improve performance. The contemporary reform movement does, however, differ in that it recommends and introduces particular methods of change to facilitate the delivery of their aspirations and sets ambitious performance targets for the sector.

\section{Perceived performance and aspirations: a chasm}

Aspirations of integration, teamwork, trust, partnering, standardization and value for money pervade within the reviews in the last 60 years and the need for alternative managerial practice within the sector to facilitate these aspirations is a common themeespecially in contemporary reports. Likewise, the presented challenges or barriers to these aspirations are remarkably similar: resistance to change, undesirable culture and fragmentation. They differ little between the contemporary reform movement and reports in the preceding 50 years except in the rhetoric used. It is nowadays not uncommon to 
hear these challenges summarized emotively as the 'illnesses' of the sector (Department of Environment Transport and the Regions, 1998), 'traditional bad ways of both thinking and practice' (Fischer and Green, 2001, p. 60), 'the plague' (Kagioglou et al., 2000) or 'blindness of the industry to its failings' (Cain, 2003, p. 2). Woudhuysen and Abley's (2004) question and book title 'Why is construction so backwards?' arguably offers another emotive statement in this genre. Regardless of the language used, it is obvious that there has clearly existed a chasm between client aspirations regarding performance and how the construction sector has actually performed in the past and present. Within this chasm, the mobilized discourse of change directs its attention in recommending methods of change and alternative managerial practice.

In the contemporary reform movement, the use of performance improvement targets is indicative of the clients' interpretation of the size of this chasm. Indeed, the assumption that ambitious productivity targets can and should be achieved is a central theme running through the reform movement (e.g. Latham, 1994; Department of Environment Transport and the Regions, 1998; National Audit Office, 2001; Rethinking Construction, 2002). The underpinning rationale is based on a broad recognition of consistently higher performance in other sectors - notably the automobile sector - and pockets of higher project performance within the construction sector itself. This higher performance is assumed to be directly attributable to 'best practice'.

\section{Contemporary mechanism for change}

The actual change sought after by the reform movement is promoted through identification, implementation, monitoring and measuring of best practice. The kind of best practice sought is largely designed to address and revisit aspirations of integration, teamwork, trust, partnering, standardization and value for money, and is, therefore, driven and biased by these aspirations. The identification of best practice is largely achieved through 'learning from other sectors' and benchmarking.

The adoption and application of best practice forms the basis for the Movement for Innovation's (Now CE's) 'demonstration projects'. These projects are monitored against a set of predetermined key performance indicators (KPIs) (Rethinking Construction, 2002), which are based on those previously published in Rethinking Construction (Department of Environment Transport and the Regions, 1998). Correlations between demonstration projects and KPI measures are used to represent the 'cause and effect' between adopting best practice and enhanced performance. The measured benefits of best practice then lend weight and support for its wider diffusion whilst also tending to act as legitimacy for their promotion by the reform movement.

\section{Challenging assumptions: discussion}

Several concerns related to the reform movement, in particular the identification and diffusion of best practice, deserve to be highlighted. First, the prominence of the correlation between adopting best practice and enhanced performance through the 
demonstration project' and KPI measures is highly questionable. This emphasis on cause and effect is primarily designed to convince others within the sector similarly to adopt best practice. What is missing is an explanation of how best practice is diffused within project environments. This is notable given that the adoption of best practice on projects is viewed as innovation. Diffusion has long been central to the study of innovation (cf. Rogers, 1995; Sundbo, 1998). Given the synonymous use of best practice and innovation, it is surprising, therefore, that reflection on diffusion would appear to be marginalized by the reform movement despite significant contributions from, for example, Winch (1998), Bresnen and Marshall (2001) and Gann (2001). Indeed, work by Bresnen et al. (2004, 2005) highlights the need for considerable reflection on specific factors relating to project-based organizations and their effect on the mediation, negotiation and shaping of change.

A second concern relates to the promotion and scrutiny of demonstration projects and howthis in itselfmay lead to change. This idea is by no means new and follows the muchcited research ofMayo (conducted at the Western Electric Hawthorne Works, 1927-32) described as the 'Hawthorne effect' - whereby singling out and observing one group of workers using different practices produced improved performance regardless of which changes were made to practice. Much of this improved productivity was discovered to have been the product of being observed and how such observation changed the social environment within which the group belonged. To what extent similar scrutiny of demonstration projects might produce a similar effect is neither reflected upon nor, indeed, noted within the reform movement. This is also true for the effect of 'potentially' added resources allocated to these projects. Furthermore, note that one difficulty with demonstrating and encouraging the propagation of best practice is echoed in accusations that KPIs have been manipulated for marketing purposes (Murray, 2003; Beatham et al., 2004).

Furthermore, methods such as benchmarking and the adoption and implementation of best practice are not without their critics (e.g. Wolfram Cox et al., 1997; Green, 2002; Barrett and Barrett, 2004). These papers tend to take a largely reflective and critical stance against such methods of change and convey concerns that these methods fall short of providing reliable explanations regarding the relationship between practice and performance. These concerns are important in challenging the discourse and content of change called for by the reform movement such as the identification of best practice (largely managerial) learning from other sectors and benchmarking (by, for example, the Construction Research and Innovation Strategy Panel), the demonstration and testing of best practice (by the Movement for Innovation), and the use of KPIs to legitimize the wider adoption of best practice (by the Construction Best Practice Programme) (National Audit Office, 2001, p. 38). Finally, there are also notable papers that broadly criticize the reform movement based on an unreflective allegiance to instrumental management techniques (Green, 2002; Green and May, 2003). Indeed, Green, albeit with a hint of sarcasm, used the phrase 'technocratic elite' as a broad descriptor for those responsible for promoting change. Whilst such concerns are inevitably related to the present paper, the objective is to explore and critique the authors' interpretation of the discourse of change. What follows, therefore, is an exploration of the methods, 
underlying assumptions and limitations. The purpose of this exploration is to challenge the thinking behind the reform movement and to contribute towards debate of current and alternative methods of change that seek to understand improvement activity within the construction sector.

\section{KPIs, measurement and strategy}

Measuring the performance of organizations is considered to be highly relevant and important (Neely, 1999; Cain, 2003; Beatham et al., 2004) as it is linked with strategy and action and part of an overarching mechanism of control. Indeed, performance measurement is argued to provide the feedback required to control and improve actions that are related to strategy (Sinclair and Zairi, 2000; Beatham et al., 2004). The measures themselves are designed to be indicative of an organization's effectiveness and efficiency and reflect how the organization has been organized and managed. In seeking to understand the impact of change in organizing or management, the need to measure and indicate the potential effect of change is, accordingly, both useful and necessary.

The emphasis on performance measurement and KPIs by the reform movement is, therefore, wholly understandable - it is about attempts to exercise a greater degree of control over the performance of the sector to improve the delivery of client aspirations. Performance measurement is also argued to be instrumental in improving the 'lot' of the sector. However, whilst monitoring performance using measures and KPIs is undoubtedly useful, doing so does not provide wholly reliable explanations for the link between practice and performance. The authors are, therefore, not arguing against the use of measurement per se, rather that measurement falls short of the rigour necessary to understand fully practice and change.

\section{Understanding and measurement}

There is a clear tension between the wish and/or need for performance measurement and the difficulty in actually doing it. Several broad criticisms of benchmarking argue that not all aspects of organizational performance can be codified and structured to make measurement possible (Wolfram Cox et al., 1997; Bresnen, 1999; Dervitsiotis, 2000). Furthermore, Wolfram Cox et al. argue that a dominant allegiance to measurement by benchmarking practitioners is related to a view that a concept attains status and legitimacy if it can be counted or measured. Bradley et al. (2000) similarly note that within management, scientific and technical rationality is presented as the only correct form of analysis and is 'seen as the only suitable yardstick by which progress or efficiency can be measured' (p. 109). Notably, the emphasis is on measurement and what can be measured.

The process of identifying best practice is heavily reliant on what can be measured. The process is, therefore, insensitive to the relationship between what can be measured, codified and adopted, and what ostensibly escapes the attention of those who measure. Within the contemporary reform movement there appears to be little recognition of what cannot be measured and an overemphasis on easily measurable and quantifiable aspects 
of performance (cf. Bresnen, 1999). It is argued here, therefore, that edicts such as 'if it can be measured, it can be benchmarked' and 'what isn't measured isn't managed' should be counterbalanced with questions surrounding what to do about those things that cannot be measured. The stripping of best practice from what cannot be measured is unlikely to provide wholly reliable explanations for what makes practice 'best' or indeed 'poor'. A recent example of this complexity can be found in the exploration and use of design quality indicators as an extension to performance improvement. This has been pursued within the reform movement with unconvincing results (Gann et al., 2003; Salter and Torbett, 2003). Gann et al. found substantial difficulties with establishing and applying indicators and subsequently realigned their thoughts on their design quality indicators as a tool for thinking rather than an absolute measure. The value was seen to be in the tool's ability to invite and extend dialogue about design quality and to facilitate reflective development by design practitioners similar to Schön's (1983) notion of the reflective practitioner. The extent to which all important aspects of performance such as design quality are measurable is therefore questionable. Indeed, so too is the extent to which all important aspects of performance can be captured in best practice.

\section{Context stripping and recontextualization}

In their benchmarking exercise, Winch and Carr (2001) questioned the relationship between measured performance and practice and concluded that reference to other aspects of practice and constraints are required. This is typically described within parts of the research community as context stripping and refers to the consequences arising from a research design that uses a 'precise' quantitative approach (Guba and Lincoln, 1998). This approach focuses on a specific set of variables and excludes from the data collection and subsequent analysis the impact of other potentially influential contextual factors.

Contextually stripping potentially important factors from a study limits the generalizability of the findings to other contexts (cf. Swan et al., 1999; Nutt, 2000). Similarly, findings generalized from one context for application in another context require recontextualization (Gavigan et al., 1999). Thus, separating influential aspects of host and receiving contexts in benchmarking studies from research designs places limitations on explaining the link between the practice under study and its performance. An overemphasis on performance measurement and the reliance on a quantitative approach to benchmarking is, thus, likely to be insensitive to issues of context stripping and recontextualization. Whilst performance improvement and measurement lay at the heart of benchmarking espoused by Camp (1989) and others (Codling, 1992; Zairi, 1992; Watson, 1993), significant emphasis was placed on the concepts ability to challenge practitioners to reflect upon assumptions and to understand practice in context. This has, however, been largely lost by an overemphasis on performance measurement by the advocates of benchmarking in the construction sector. Thus, best practice and benchmarking fail to provide explanations for the relationship between managerial practice and performance used elsewhere and its adoption (successful or not) in the construction sector is therefore limited. 
It is, therefore, evident that seeking to understand and explain the link between practice and performance is problematic and only partly possible via the use of measures and KPIs. Further support for this argument can be found in, for example, Kagioglou et al. (2001), Hall and Holt (2003) and Beatham et al. (2004), who all recognize the need for measures to be subsumed within an overall supportive performance management system. Their emphasis lies with using measures as the basis for continuously reflecting upon and taking action (Beatham et al., 2004), reflecting upon organizational strategy (Kagioglou et al., 2001) and performance learning (Hall and Holt, 2003). Such work is highly commendable as, whilst it concedes that KPIs and performance measurement are necessary, they attempt to shift the emphasis towards dialogue, reflection and learning.

\section{Universalistic assumptions of best practice}

Universalistic assumptions regarding the application and implementation of best practice brings with it a number of criticisms. Purcell (1999), for example, argues that the simplistic search for and adoption of best practice is like being led down a utopian culde-sac. This line of reasoning challenges best practice research. It is argued that best practice has to be coupled with the need to understand the circumstances within which it is used, when it is used and why (Youndt et al., 1996; Harrison, 1998; Marchington and Grugulis, 1998; Martin and Beaumont, 1998; Wood and De Menezes, 1998; Purcell, 1999). Indeed, research relating to the circumstances in which successful companies do not use best practice and why they do not use best practice may be as rich in learning as the former. Therefore, there is an argument for a move away from imitation on the basis of simplistic cause and effect to a position that concedes learning to be drawn from understanding and challenging 'cause and effect' in its context. Effectively, it is argued that notions of learning and knowledge sharing have much to contribute towards achieving better organizational performance and understanding the link between practice and performance. Whilst the above-mentioned authors are largely rooted in human resource management, their criticism of the universalistic approaches inherent in best practice would appear to be equally valid elsewhere. Compare, for example, the concept of competitive disadvantage that is slowly emerging within strategy research. The leading hypothesis within this field has long been that sustained superior performance arises from sustainable competitive advantages (Barney, 1997; Roberts, 1999; Grant, 2002). Competitive advantage and competitive disadvantage are quite independent, i.e. if competitive advantage arises from inimitable, idiosyncratic resources then competitive disadvantage is not merely the non-existence of such resources. Rather, competitive disadvantage is the failure to satisfy even the minimum success requirements (Powell, 2001). Thus, it is quite possible for an organization to demonstrate several competitive advantages without showing superior performance. It is also possible, therefore, that an organization may be using best practice in a number of areas within its business operations without any improvement on performance.

These warnings highlighting the limitations of best practice find little resonance with the arguments for adopting best practice within the reform movement. Indeed, despite Green's (2002) notable contribution of a critical perspective on the instrumental rationality of best practice and its relation to the technocratic elite, the uncritical 
acceptance of universalistic assumptions in the contemporary change agenda continues to dominate. This paper challenges the reform movement to think again and shift their position away from one that attempts to lead the sector down a utopian cul-de-sac.

\section{Diffusing best practice: resonance}

Underlying the idea of adopting best practice is the assumption that it is similarly interpreted by individuals charged with the tasks of either implementation or application. Yet, there are undoubtedly an infinite number of reasons why employees and managers within an organization may obstruct management initiatives recommending alternative practice. This could to some extent be explained by looking at how the risks inherent in change efforts are valued. In their seminal work on prospect theory, Kahneman and Tversky (1979) show that individuals do not value the chance of future gains as highly as the chance to reduce future loses, i.e. individuals are risk averse. Taking a different perspective, explanation could be found in the concept of 'resonance' (Hodder, 1998) whereby legitimacy is given to creative ideas if, and only if, they resonate with the concerns of individuals (or groups of individuals).

Further insights could be gained from looking at research that has been conducted within the field of human resource management studies. Truss (2001), for example, argues that there is a need to understand the 'informal organization' as a significant contributor to the way the relationship between human resource management (HRM) and organizational performance is conceptualized and investigated. A similar line of inquiry was taken by Marchington and Grugulis (1998, p. 1117) who stated:

as managements are not omniscient, omnipresent, and omnipotent, because they lack cohesiveness and typically engage in political behaviour, it is probably impossible to determine at an empirical level whether or not best practice HRM is universally applicable.

Whilst these arguments focus on the idea of best practice HRM, the criticism of best practice per se is a useful insight to its limitations and underlying assumptions and ought to be equally valid for those responsible for interpreting and legitimizing best practice elsewhere. Notably, such arguments and criticism largely remain outwith the edicts and arguments of the reform movement and, indeed, much of the construction management literature.

However, it is not only on the individual and organizational level that differences in how best practice is perceived could arise. It is also clearly possible - indeed likely - that reformers setting the agenda for change have distinctively different (if not conflicting) agendas to the employees and managers. Essentially the implementation of any form of non-incremental innovation (change) will inevitably challenge existing interest groups and destabilize existing partnerships (Kimberley, 1981). This indirectly concedes that the successful application of practice in one sector is highly dependent on its compatibility with interest groups and partnerships within that sector or organization. These insights are prevalent within the study of innovation systems (cf. Lundvall, 1992; Nelson and 
Rosenberg, 1993; Edquist, 1997) and has also been highlighted in studies of technological evolution (cf. Freeman, 1982). An understanding of the performance of a practice must simultaneously be rooted in an understanding of what it means to existing interest groups and partnerships.

\section{View from somewhere: assumptions}

Criticism can be either constructive or destructive. If the latter, it may well be both interesting and suggestive, but it is likely to fail in dislodging any received view. It has therefore been contended that for criticism to be effective it has to offer a viable alternative i.e. be constructive (Bunge, 1985). Whilst this position is not necessarily wholly supported, what follows is an attempt to present such a viable alternative.

From a philosophical perspective, it is possible to align notions of best practice, universalism and an overemphasis on measurement with a view that knowledge is universal and objective. In this sense, these concepts subscribe to a kind of knowledge sought that is described by Dolling (2003) as ahistorical, acontextual and, above all, timeless - alternatively 'the view from nowhere'. Such a view is juxtapositioned with 'the view from somewhere' - where knowledge is sought that is context dependent, based on hermeneutics where truth is emergent, and a result of hermeneutic experience (cf. Shapin, 1998).

The development of 'the view from somewhere' in this paper is to be considered as an alternative way of reflecting upon and understanding change. A number of assumptions are put forward for the perusal and critical gaze of others. They outline a step in a particular direction and are by no means prescriptive - rather they are in the process of development where further criticism is both necessary and welcome to fuel reflection.

\section{Context and practice}

Failure to understand and relate initiatives to context is understood to be the reason why many contemporary change programmes consistently fail to deliver (Beer et al., 1993). Following this line of reasoning it is argued that in seeking to understand managerial practice it is essential that context is recognized as an influential aspect of any analysis of managerial practice or those recommending change. Indeed, from a change management perspective it is surely common sense to understand fully why and how organizations and individuals legitimize current practice before prescribing a need for change and how such change might be implemented. This point is not lost on theorists within organization studies who have recently explored the use of theories such as structuration (Pozzebon, 2004), institutionalism (Child, 1997; Barley and Tolbert, 1997) and evolutionary economics (Massini et al., 2002) that highlight the importance of various aspects of context. Thus, from the perspective of this paper structuration theory, institutionalism and evolutionary economics represent useful sources that highlight the need for contextual thinking and sensitivity within organizational studies and in the discourse mobilized by the contemporary reform movement in the construction sector. 
The recognition of context and the pivotal role it plays in shaping and being shaped by contemporary managerial practice should be of prime concern to policy-makers, practitioners and academics engaged in advocating change within the sector. Historically, industry commentators as far back as Higgin and Jessop (1965) and the Tavistock Institute (1966) have, indeed, made attempts to conceptualize and understand context when addressing such issues as interdependency, communication and uncertainty in the construction sector. However, almost paradoxically, the contemporary change agenda appears to be narrowly focused on the need to adopt alternative managerial practice and, hence, tends to underplay or ignore the importance of context in their analyses (cf. Cox and Townsend, 1997; Love et al., 2000, Cox and Ireland, 2002).

A core argument of this paper is that practice is not enacted within a vacuum. In essence, analysis of change, recommendations for change, implementation of change and an understanding of the status quo must be sensitive to the dynamic relationship between context and practice. Failure to do so run the risk of making any associated change initiatives partly or wholly irrelevant. It is contended that such thinking and sensitivity is under developed within the methods recommended and used by the reform movement.

It is, however, important to note that context is by no means a simplistic or static entity since it concerns a raft of highly complex, dynamic and influential factors. This understanding leads Pettigrew (1997) to suggest an outer and inner context that helps to determine the features of a practice. Practice is embedded within and is mediated by context. This relationship is symbiotic as context is also shaped and reinforced by practice. Attempts to change the context can therefore be as influential and important as attempts to change practice when challenging the status quo. In essence, context and practice should be viewed as different aspects of the same reality (Walsham, 1993) and the temptation to treat them as separate units of analysis should be resisted. Reality is, however, subjective as it is dependent on the individual. In this sense, the view from somewhere relates to an individual's interpretation of something (practice) somewhere (context) as the basis of action. Research is needed that engages this reality by similarly engaging with construction sector practitioners to understand the legitimacy of their actions and their reactions to the content of change.

\section{The heavy hand of the past}

Further to the importance of the structural characteristics of context, it is also necessary to recognize that different industry sectors and organizations are characterized by recipes (Spender, 1996), logics (Pettigrew and Whipp, 1993; Shaw, 2002) and organizational routines (Massini et al., 2002) that reflect a historical understanding of both context and practice. Thus, it can be argued that practice inevitably 'reflects and reinforces', 'shapes and is shaped by' associated deepseated rules and assumptions, industry recipes or logics over time. In this sense, context and practice represent interconnected aspects of the same reality (Walsham, 1993) and assumptions regarding both context and practice could be argued to be carried forward in the human consciousness (Pettigrew, 1997). Aetiology, the philosophical study of causation, has been given very little attention in the construction literature and much more emphasis has been put on describing the 
'symptoms' than in unravelling their origins. This could be compared with the field of medical research where aetiological approaches are well established. Whilst an accurate and extensive aetiological explanation of contemporary construction practice is implausible, it is contended here that an insight into historical events, ultimately, reveals a more comprehensive understanding of evolving and emergent context and practice.

Methodological support for research that addresses the heavy hand of the past can be found in both structuration theory and new institutionalism. In structuration theory, actors are argued to draw upon knowledge and capabilities that are historical accretions of past practice and understandings. Such knowledge and capabilities are argued to inform the way in which actors act and reflect the use of: interpretative schemes to make sense of behaviours and events; facilities (their command over people and resources) to mobilize available resources; and norms to sanction behaviours and events, thus conferring legitimacy to, for example, current or emergent practice. Such knowledge and capabilities are therefore instrumental in shaping, and being shaped by change, and cannot be disconnected from any understanding of the process of diffusion for change. Structuration theory, therefore, seeks to guide the researcher to engage with and seek to understand knowledgeable and reflexive actors and how they bring their understanding (informed by the past) to the process of diffusion. Similarly, institutional theory views social actors as being engaged in creating and using existing (through interpretative processes) recipes, logics, routines, rules, assumptions or institutions to interpret change. Hence, institutions are encoded in actors' stocks of practical knowledge and influence how people communicate, enact knowledge and sanction behaviour. Change cannot be divorced from such knowledge accumulated through time by social actors.

Insights into managerial practice, change and innovation diffusion can be drawn from research that attempts to catch reality in flight (Pettigrew, 1997) that is shaped by and through time. In his work on exploring continuity and change within ICI, Pettigrew (1985) presents such a process and indicates that such research is largely longitudinal in nature. However, there are few examples of such longitudinal research within the construction sector. Indeed the demands placed upon researchers by funding institutions to complete research within short timeframes leave little room for longitudinal research designs.

\section{Contextual approaches}

The need for an approach that concedes to a 'view from somewhere' is considered in this paper as a way to reflect appropriately upon and understand change. It is also worth noting that such an approach would be largely instrumental in reflecting upon and understanding the legitimacy of current practice within the construction sector. There are a number of significant theoretical contributions to the debate surrounding the development of contextual approaches in sociology and organization studies. Notable contributions come from structuration theory (Giddens, 1984), new institutionalism (DiMaggio and Powell, 1991; Scott and Meyer, 1991) and sense-making (Weick, 1995). Here structuration theory is offered as a suitable foundation for a 'view from somewhere'. Whilst it, inevitably, is offered to the reader in the hope that it will be 
considered convincing, this is not the major purpose. It is offered as a 'for instance', albeit one that the authors find convincing. Like all philosophical and methodological choices, it is contestable as to its logic and vulnerability to rival arguments. It is entirely accepted and acceptable that others might support other perspectives.

There are a number of examples that draw on structuration theory to develop microapproaches for the broad analysis of organizations (e.g. Whittington, 1992; Bouchikhi, 1993; Orlikowski, 2001), processes (e.g. Pettigrew, 1997), inter-organizational networks (e.g. Sydow and Windeler, 1998; Sydow and Staber, 2002) and strategy (e.g. Pozzebon, 2004). The view of such researchers follows a pattern that posits organizations as social systems where practices or processes are constantly being transformed, discarded or reinforced through the actions of organizational participants. These participants are knowledgeable and reflexive, they use:

- interpretative schemes to make sense of behaviours and events through communication that reproduce the rules of signification (Bryant and Jary, 2001)

- facilities (their command over people and resources) to mobilize available resources thus translating power into domination (Bryant and Jary, 2001)

- norms to sanction behaviours and events thus conferring legitimacy (Staber and Sydow, 2002)

For Staber and Sydow (2002, p. 413), organizational participants/practitioners:

face the same challenges as in larger societal settings when responding to and using the social structures in which they are embedded, by settling disputes, compromising, negotiating, evaluating, risk taking, and so forth.

There have also been a number of organization study researchers who have drawn upon and used the theory of structuration as a meta-theory to challenge the dualism of structure and agency in conceptions of organizations and management (e.g. Willmott, 1987, 1999; Whittington, 1992; Hung and Whittington, 1997; Pettigrew, 1997; Orlikowski, 2001; Staber and Sydow, 2002). For example, Willmott's (1987) examination of conceptualizations of management found a trend towards abstracting the behaviour of managers from structure. Structuration theory he proposed would advance studies of managerial work by accepting the duality of structure and action. The rising importance of structuration theory in organization and management studies is also noted by Whittington (1992), Brooks (1997) and Pozzebon (2004) as indicative of the relevance of Giddens work to organizational research approaches. Indeed, reflecting this rise in importance of structuration theory, Green et al. (2005) and Bresnen et al. (2004, 2005) have also both recently drawn upon structuration theory to inform their research endeavours in the context of the construction sector and indeed change.

There are, thus, no shortages of approaches that are sensitive to the recursive relationship between context and practice from which organizational scholars can draw from in 
exploring change and the legitimacy of current managerial practice. Understanding the legitimacy of current managerial practice is of particular concern to the authors of this paper. In essence, it is argued that it is necessary to understand the sector from this perspective prior to meditating upon and challenging the sector to change in particular ways. This has been under explored and undeveloped within the discourse of change and arguably is reflected within a long line of change initiatives that have failed to penetrate the sector over a significant number of years. These initiatives have failed to understand the legitimacy of managerial practice and tend to talk of barriers in the sector to aspirations of change (Murray and Langford, 2003). Contextual approaches informed by structuration theory therefore offer much too organizational scholars keen to explore change in the construction sector and engage with the legitimacy of current managerial practice.

\section{Summary and conclusions}

This paper attempts: to unravel the discourse mobilized by the reform movement; critique the assumptions that underpin the content of change called for by the reform movement and propose an alternative approach to understand the legitimacy of managerial practice and change in context. It effectively draws on a number of organization scholars in dismissing best practice as fundamentally flawed as a basis to shape and direct any content of change for the construction sector. The reform movement's allegiance to approaches based on best practice is also dismissed as acontextual, unreflective and insufficient in providing wholly reliable explanations for the relationship between practice and performance. Indeed, it is unclear why the reform movement has failed to engage in an exercise to understand the current legitimacy of managerial practice in the construction sector over repeated attempts to describe the sector as 'ill' and in need of reform and change. Is it possible that perceived barriers to change such as adversarial contractual relationships and opportunistic behaviour are legitimate actions of practitioners embedded in the context of the construction sector? If so, simplistic calls for change associated with collaborative working from the reform movement will continually fail to resonate with practitioners. Indeed, it is argued that it is incumbent on the reform movement to understand fully the legitimacy of current managerial practice in the construction sector before any calls for change. What is needed to address this problem is a better ongoing connection between the reform movement and organizational scholars specifically concerned with using structuration theory, for example, to understand the legitimacy of current managerial practice and change. Such a connection would bring a greater degree of resonance between the content of change and the practitioners within the construction sector responsible for change. This paper, therefore, recommends research that draws from structuration theory in engaging with and understanding the legitimacy of managerial practice in the construction sector. Such research would be longitudinal in nature and be inextricably connected to the policy-makers of the construction sector traditionally responsible for promoting change. Without such research and connections the sector is doomed to re-enact the failures of the past and to perpetuate the cycle of fad generation that has characterized the sector over the last decade. 
As a parting note, the authors feel it necessary to counter arguments that they are simply attempting to replace one set of orthodox ideas for another. This would be to misunderstand the intent of the authors as critical researchers. The intent of the paper is to inform and challenge the reform movement regarding its assumptions in a way that is meant to be constructive. The paper is intended to open the floor for debate that is informed by a clear understanding of the assumptions underpinning the reform movement and the contextual approaches outlined in the latter part of the paper.

\section{References}

Barley, S.R. and Tolbert, P.S. (1997) Institutionalization and structuration: studying the links between action and institution, Organization Studies, 18(1), 93-117

Barney, J.B. (1997) Gaining and Sustaining Competitive Advantage. Addison-Wesley, Reading, MA

Barrett, P.S. and Barrett, L.C. (2004) Research as a kaleidoscope on practice, Construction Management and Economics, 21, 755-766

Beatham, S., Anumba, C., Thorpe, T. and Hedges, I. (2004) KPIs: a critical appraisal of their use in construction, Benchmarking, 11(1), 93-117

Beer, M., Eisenstat, R.A.,and Spector, B. (1993) Why change programs don’t produce change in C. Mabey and B. Mayon-White (eds) Managing Change, London, Paul Chapman Publishing, 99-107

Bouchikhi, H. (1993). A constructivist framework for understanding entrepreneurship performance, Organization Studies, 14(4), 549-570

Bradley, H., Erickson, M., Stephenson, C. and Williams, S. (2000) Myths at work, Polity Press and Blackwell, UK

Bresnen, M. (1999) Linking Construction Research to Research and Innovation in Other Sectors: Institutional and cultural barriers to effective knowledge transfer, CRISP publication

Bresnen, M. and Marshall, N. (2001) Understanding the diffusion and application of new management ideas in construction, Engineering, Construction and Architectural Management, 8(5/6), 335-345

Bresnen, M., Goussevskaia, A., Swan, J. (2004) Embedding New Management Knowledge in Project-Based Organizations, Organization Studies, 25(9), 1535-1555

Bresnen, M., Goussevskaia, A., Swan, J. (2005) (forthcoming) Implementing change in construction based organizations: exploring the interplay between structure and agency, Building Research and Information, 33(6) 
Brooks, L. (1997) Structuration theory and new technology: analysing organizationally situated computer-aided design, Journal of Information Systems, 7, 133-151

Bryant, C. G. A. and Jary, D. (2001) Anthony Giddens: a global social theorist, in C. G. A. Bryant and D. Jary (eds) The Contemporary Giddens, Basingstoke, Palgrave, 3-39

Bunge, M. (1985) Philosophy of Science and Technology, Treatise on Basic Philosophy (Vol. 7, Part 1) - Epistemology and methodology III. D. Riedel Publishing Company, Dordrecht, Holland

Cain, C.T. (2003) Building Down Barriers: a guide to construction best practice, Taylor and Francis, London

Camp, R. C. (1989) Benchmarking: The search for best practices that lead to superior performance, Quality Press, London

Child, J. (1997) Strategic choice in the analysis of action, structure, organizations and environment: retrospect and prospect, Organization Studies, 18(1), pp. 43-76

Codling, S. (1992) Best Practice Benchmarking: The management guide to successful implementation, Gower, UK

Confederation of Construction Clients (CCC) (2000) The Clients' Charter Handbook, CCC

Constructing Excellence (2004) Constructing Excellence: A strategy for the future, Constructing Excellence, London

Construction Manager (2004) Assessing the legacy, Construction Manager, October, 1417

Cox, A. and Ireland, P. (2002) Managing construction supply chains: the common sense approach, Engineering, Construction and Architectural Management, 9(5/6), 409-418

Cox, A. and Townsend, M. (1997) Latham as a half-way house: a relational competence approach to best practice in construction procurement, Engineering, Construction and Architectural Management, 4(8), 143-158.

Dervitsiotis, K.N. (2000) Benchmarking and business paradigm shifts, Total Quality Management, 11(4/5\&6), 641-646

DETR (1998) Rethinking Construction, London: Department of Environment Transport and the Regions

DiMaggio, P.J. and Powell, W.W. (eds) (1991) The New Institutionalism in Organisational Analysis, The University of Chicago Press, Chicago and London 
Dolling, L. M. (2003). Dialogue as praxis: Philosophic hermeneutics, historical epistemology, and truth. In C. C. Gould (ed.) Constructivism and Practice, Rowman and Littlefield, Maryland.

Edquist, C. (1997) Systems of Innovation Approaches - Their Emergence and Characteristics. In C. Edquist (ed) Systems of Innovation, Pinter, London

Finch, P. (2000) Better public buildings: a proud legacy for the future, a report published by the Department for Culture Media and Sport, London

Fischer, N. and Green, S. (2001) Partnering and the UK construction industry the first ten years - a review of the literature, in National Audit Office (NAO) (2001) Modernising Construction, The Stationary Office, London, 58-66

Freeman, C. (1982) The Economics of Industrial Innovation $2^{\text {nd }}$ edition, Frances Pinter, London.

Gann, D. (2001) Putting academic ideas into practice: technological progress and absorptive capacity of construction, Construction Management and Economics, 19, 321330.

Gann, D.M., Salter, A.J. and Whyte, J.K. (2003) Design quality indicator as a tool for thinking, Building Research and Information, 31(5), 318-333

Gavigan, J.P., Ottitsch, M. and Mahroum, S, (1999) The Futures Project, Knowledge and Learning: Towards a learning Europe, European Commission Directorate - General JRC Joint Research Centre, Institute for prospective technological studies, TECS Futures programme

Giddens, A. (1984) The constitution of society. University of California Press, Berkeley, CA.

Grant, R.M. (2002) Contemporary Strategy Analysis, $4^{\text {th }}$ edition. Blackwell Publishing, Oxford.

Green, S. D. (2002) The human resource management implications of lean construction: critical perspectives and conceptual chasms, Journal of Construction Research, 3(1), 147-166

Green, S.D. and May, S.C. (2003) Re-engineering construction: going against the grain, Building Research and Information, 31(2), 97-106

Green, S.D., an May, S. (2005) Lean construction: arenas of enactment, models of diffusion an the maning of 'leanness', Building Research and Information, 33(6) 
Green, S.D., Fernie, S., Weller, S. (2005) Making sense of supply chain management: a comparative study of aerospace and construction, Construction Management and Economics, 23(6), 579-593

Guba, E.G. and Lincoln, Y.S. (1998) Competing Paradigms in Qualitative Research, in D.K. Denzin and Y.S. Lincoln (Eds) The Landscape of Qualitative Research: Theories and Issues, Sage Publications, California.

Hall, M. and Holt, R. (2003) Developing a culture of performance learning in U.K. public sector project management, Public Performance and Management Review, 26(3), 263275

Harrison, A. (1998) Horses for courses: human aspects of different logistics systems, International Journal of Logistics, 2(3), 247-261

Higgin, G. and Jessop, N. (1965) Communications in the building industry: the report of a pilot study, Tavistock publications, London

Hodder, I. (1998) Creative thought: a long term perspective. In S. Mithen (Ed.), Creativity in Human Evolution and Prehistory, Routledge, London

Hung, S.-C. and Whittington, R. (1997) Strategies and Institutions: A pluralistic account of strategies in the Tiawanese computer industry, Organization Studies, 18(4), 551-575

Kagioglou, M., Cooper, R. and Aouad, G. (2001) Performance management in construction: A conceptual framework, Construction Management and Economics, 19(2), 85-95

Kagioglou, M., Cooper, R., Aouad, G. and Sexton, M. (2000) Rethinking construction: the Generic Design and Construction Process Protocol, Engineering, Construction and Architectural Management, 7(2), 141-153

Kahneman, D. and Tversky, A. (1979) Prospect Theory: An Analysis of Decision Under Risk. Econometrica, 47(2), 263-291

Kimberley, J.R. (1981) Managerial innovation, in P.C. Nystrom and W.H. Starbuck (eds) Handbook of Organizational Design, 84-104

Latham, M. (1994) Constructing the Team: Joint Review of Procurement and Contractual Arrangements in the United Kingdom Construction Industry. London: HMSO

Love, P.E.D., Li, H., Irani, Z. and Faniran, O. (2000) Total Quality Management and the learning organisation: a dialogue for change in construction, Construction Management and Economics, 18, 321-331. 
Lundvall, B-Å. (ed.) (1992) National systems of Innovation: Towards a Theory of Innovation and Interactive Learning. Pinter, London

Marchington, M. and Grugulis, I. (1998) Best practice human resource management: perfect opportunity or dangerous illusion?, International Journal of Human Resource Management, 11(6), 1104-1124

Martin, G. and Beaumont, P. (1998) Diffusing 'best practice' in multinational firms: prospects, practice and contestation, The International Journal of Human Resource Management, 9(4), 671-695

Massini, S., Lewin, A.Y., Numagami, T. and Pettigrew, A.M. (2002) The evolution of organizational routines among large Western and Japanese firms, Research policy, 31, 1333-1348.

Murray, M. (2003) Rethinking Construction: The Egan report (1998), in Mike Murray and David Langford (eds) Construction Reports 1944-98, Blackwell, Oxford, 178-194

Murray, M. and Langford, D., Ed. (2003) Construction Reports 1944-98. Oxford, Blackwell

National Audit Office (NAO) (2001) Modernising Construction, The Stationary Office, London

National Audit Office (NAO) (2005) Improving Public Services through better construction, The Stationary Office, London

Neely, A. (1999) The performance measurement revolution: why now and what next?, International Journal of Operations and Production Management, 19(2), 205-228

Nelson, R.R. and Rosenberg, N. (1993) Technical Innovation and National Systems. In R.R. Nelson (ed.) National Innovation Systems: A Comparative Study, Oxford University Press, Oxford

Nutt, P.C. (2000) Decision-making success in public, private and third sector organisations: finding sector dependent best practice, Journal of Management Studies, 37(1), 77-108

Office of Government Commerce (OGC) (2003) Increasing Competition and Improving Long-Term Capacity planning in the Government Market Place, OGC Report to the Chancellor of the Exchequer

Orlikowski, W. J. (2001) The duality of technology: rethinking the concept of technology in organizations, in C. G. A. Bryant and D. Jary (eds) The Contemporary Giddens, Basingstoke, Palgrave, 62-96 
Palmer, I., and Dunford, R. (2002) Managing discursive tension: The co-existence of individualist and collaborative discourses in Flight Centre, Journal of Management Studies, 39(8), 1045-1069

Parker, I. (1992) Discourse Dynamics: Critical Analysis For Social And Individual Psychology, Routledge, London

Pettigrew, A. M. (1985) The Awakening Giant: Continuity and Change in ICI, Basil Blackwell, London

Pettigrew, A. M. (1997) What is a processual analysis?, Scandinavian Journal of Management, 13(4), 337-348.

Pettigrew, A. and Whipp, R. (1993) Understanding the environment in C. Mabey and B. Mayon-White (Eds) Managing Change, Paul Chapman Publishing, London, 5-19

Phillips, N., and Hardy, C. (2002) Discourse analysis. Investigating processes of social construction, Sage Publications, Thousand Oaks, California

Powell, T.C. (2001) Competitive advantage: logical and philosophical considerations. Strategic Management Journal, 22, 875-888.

Pozzebon, M. (2004) The influence of a structurationist view on strategic management research, Journal of Management Studies, 41(2), 247-27

Purcell, J. (1999) Best practice and best fit: chimera or cul-de-sac?, Human Resource Management Journal, 9(3), 26-41

Rethinking Construction (2002) Rethinking Construction: 2002 Achievements, Next Steps and Getting Involved, Rethinking Construction, London

Roberts, P.W. (1999) Product innovation, product-market competition, and persistent profitability in the U.S. pharmaceutical industry. Strategic Management Journal, 20(7), $655-670$

Rogers, E.M. (1995) Diffusion of Innovations, $4^{\text {th }}$ edition. The Free Press, New York Salter, A. and Torbett, R. (2003) Innovation and performance in engineering design, Construction Management and Economics, 21, 573-580

Schön, D.A. (1983) The Reflective Practitioner: How professionals think in action, Basic Books, Inc

Scott, W. R. and Meyer, J.W. (1991) The organization of societal sectors: propositions and early evidence, in W. W. Powell, and P.J. DiMaggio (eds) The New Institutionalism in Organizational Analysis, The University of Chicago Press, Chicago 
Shapin, S. (1998) Placing the view from nowhere: historical and sociological problems in the location of science, Transactions of the Institute of British Geographers, 23(1), 5-12 Shaw, P. (2002) Changing conversations in organisations: a complexity approach to change, Routledge, London

Sinclair, D. and Zairi, M. (2000) Performance measurement: a critical analysis of the literature with respect to total quality management, International Journal of Management reviews, 2(2), 145-168

Spender, J.-C. (1996) Making knowledge the basis of a dynamic theory of the firm, Strategic Management Journal, 17, 45-62

Staber, U. and Sydow, J. (2002) Organizational adaptive capacity: a structuration perspective, Journal of Management Inquiry, 11(4), 408-424

Strategic Forum for Construction (2002) Accelerating change, Rethinking Construction, London

Sundbo, J. (1998) The theory of innovation: entrepreneurs, technology and strategy. Elgar Publishing Ltd, Cheltenham, UK

Swan, J., Newell, S. and Robertson, M. (1999) The illusion of 'best practice' in information systems for operations management, European Journal of Information Systems, 8, 284-293

Sydow, J. and Staber, U. (2002) The institutional embeddedness of project networks: The case of content production in German television, Regional Studies 36(3), 215-227

Sydow, J. and Windeler, A. (1998) Organizing and evaluating inter-firm networks: A structurationist perspective on network processes and effectiveness, Organization Science, 9, 265-284

Tavistock Institute (1966) Interdependence and Uncertainty: A Study of the Building Industry, Tavistock Publications, London

Truss, C. (2001) Complexities and controversies in linking HRM with organizational outcomes, Journal of Management Studies, 38(8), 1121-1149

Walsham, G. (1993) Management Science and organizational change: a framework for analysis in C. Mabey and B. Mayon-White (Eds) Managing Change, Paul Chapman Publishing, London, 187-196

Watson, G. H. (1993). Strategic Benchmarking: How to rate your company's performance against the worlds best, John Wiley and Sons, London

Watson, T. J. (1997) Languages within languages: a social constructionist perspective on multiple managerial discourses in F. Bargiela-Chiappini, and S. Harris (Eds) Languages 
of Business: An Intenational Perspective, Edinburgh University Press, Edinburgh, 211227.

Weick, K. E. (1995) Sensemaking in Organisations, Sage Publications, California Whittington, R. (1992) Putting Giddens into action: Social systems and managerial agency, Journal of Management Studies, 29(6), 693-712

Willmott, H. (1987) Studying managerial work: a critique and a proposal, Journal of Management Studies, 24(3), 249-270

Willmott, R. (1999) Structure, agency and the sociology of education; rescuing analytical dualism, British Journal of Sociology of Education, 20(1), 5-21

Winch, G. (1998) Zephyrs of creative destruction: understanding the management of innovation in construction, Building Research and Information, 26(4), 268-279

Winch, G. and Carr, B (2001) Benchmarking on-site productivity in France and the UK: a calibre approach, Construction Management and Economics, 19, 577-590

Wolfram Cox, J. R., Mann, L. and Samson, D. (1997) Benchmarking as a mixed metaphor: Disentangling assumptions of competition and collaboration, Journal of Management Studies, 34(2), 285 - 314

Wood, S. de Menezes, L (1998) High commitment management in the UK: Evidence from the workplace industrial relations survey and employers manpower and skills survey, Human Relations, 51(4), 485-515

Woudhuysen, J. Abley, I. (2004) Why is Construction so Backwards?, Wiley-Academy, Chichester

Youndt, M., Snell, S., Dean, J. and Lepak, D. (1996) Human resource management, manufacturing strategy and firm performance, Academy of Management Journal, 39(4), 836-866

Zairi, M. (1992) Competitive Benchmarking: An executive guide, Technical communications, London 